\title{
Pengaruh Ekstrak Daun Duku (Lansium domesticum Corr. Serr.) terhadap Mortalitas Larva Aedes aegypti (Diptera: Culicidae)
}

\author{
Ismalia Husna 1
}

1Departemen Parasitologi, Fakultas Kedokteran, Universitas Malahayati

\begin{abstract}
Effect of Lansium domesticum Corr.Serr. Extract for Mortality Aedes aegypti Larvae (Diptera: Culicidae). Aedes aegypti is a vector of dengue hemorrhagic fever (DHF), which until now there is no drug or vaccine. The only way to eradicate transmission from dengue disease is to control vectors, but the vector control that is currently often done is with chemical insecticides which can cause environmental resistance and pollution if used continuously. Therefore, controlling using natural insecticides derived from plant extracts is one solution that until now has been developed by researchers. One of the Plant that have the potential as natural insecticides is duku ( Lansium domesticum ). This study aims to determine the concentration of duku leaf extract in causing the death of Aedes aegypti larvae. This study used duku leaf extract with 5 concentrations which were $0,2 \%, 0,4 \%$, $0,6 \%, 0,8 \%, 1,0 \%$ and $0 \%$ as controls. The results showed that for 24 hours the exposure of extracts obtained LC50 and LC90 were $0,22 \%$ and $0,32 \%$, and for 48 hours exposure obtained LC50 and LC90 were $0,07 \%$ and $0,12 \%$. Morphological changes in Ae. aegypti larvae was damage of anal papilla and blackened chiffon. The conclusion of this study was duku extract have affect mortality effect to Ae. aegypti's larvae and the most effective concentration was $0,2 \%$.
\end{abstract}

Keywords: Aedes aegypti, Lansium domesticum, plant extract, DHF

\begin{abstract}
Abstrak: Pengaruh Ekstrak Daun Duku (Lansium domesticum Corr.Serr.) terhadap Mortalitas Larva Aedes aegypti (Diptera: Culicidae). Aedes aegypti merupakan vektor dari penyakit demam berdarah dengue (DBD) yang sampai saat ini obat maupun vaksinnya belum ada. Satu-satunya cara pemberantasan transmisi dari penyakit DBD adalah dengan pegendalian vektor, namun pengendalian vektor yang saat ini sering dilakukan adalah dengan insektisida kimia yang notabenenya dapat mengakibatkan resistensi dan pencemaran lingkungan jika digunakan secara terus-menerus. Karena itu pengendalian dengan menggunakan insektisida alami yang berasal dari ekstrak tanaman merupakan salah satu solusi yang sampai saat ini kiat dikembangkan oleh para peneliti. Tanaman yang berpotensi sebagai insektisida alami salah satunya adalah duku (Lansium domesticum). Penelitian ini bertujuan untuk mengetahui konsentrasi dari ekstrak daun duku dalam menimbulkan kematian larva Aedes aegypti. Penelitian ini menggunakan ekstrak daun duku dengan 5 konsentrasi yaitu $0,2 \%, 0,4 \%, 0,6 \%, 0,8 \%, 1,0 \%$ dan $0 \%$ sebagai kontrol. Hasil penelitian menunjukkan bahwa selama 24 jam pemaparan ekstrak didapatkan nilai LC50 dan LC90 adalah 0,2\% dan 0,3\%, dan selama 48 jam pemaparan didapatkan nilai LC50 dan LC90 sebesar 0,07\% dan 0,12\%. Perubahan morfologi pada larva Ae. aegypti yang terjadi adalah rusaknya papil anal dan menghitamnya sifon. Kesimpulan dari penelitian ini adalah ekstrak daun duku berpengaruh terhadap mortalitas larva Ae. aegypti dengan konsentrasi efektif yaitu $0,2 \%$.
\end{abstract}

Kata kunci: Aedes aegypti, Lansium domesticum, ekstrak tanaman, DBD. 


\section{PENDAHULUAN}

Penyakit Demam Berdarah Dengue (DBD) merupakan salah satu masalah kesehatan, khususnya di negara-negara yang memilki iklim tropis seperti Indonesia dan nyamuk Aedes $s p$ merupakan vektor yang dapat menularkan penyakit DBD tersebut (Safar, 2009; Wong et al, 2013).

Dua spesies Aedes yang dapat menularkan virus DBD ke manusia, yaitu Ae. aegypti dan Ae. albopictus. DBD merupakan penyakit yang disebabkan oleh 4 famili virus Flaviviridae, yaitu DENV-1, DENV-2. DENV-3, dan DENV-4. Virus tersebut terdiri atas rantai tunggal RNA yang mengalami replikasi pada tubuh nyamuk dari genus Aedes (Guerdan, 2010). Tahun 2014 tercatat penderita DBD di 34 provinsi di Indonesia sebanyak 71.668 orang dan 641 orang diantaranya meninggal dunia. Data tersebut lebih rendah dibandingkan pada tahun 2013 dengan jumlah penderita mencapai 112.511 orang dan 871 orang diantaranya meninggal dunia (Kemenkes, 2015).

Sampai saat ini belum ada obat dan vaksin untuk penyakit DBD tersebut, karena itulah pemberantasan penyakit DBD dilakukan dengan pengendalian vektor, namun pemakaian insektisida secara terus menerus dapat mencemarkan lingkungan, mengganggu ekosistem, bersifat toksik terhadap organisme hidup, dan dapat menimbulkan resistensi vektor terhadap insektisida tersebut (Kumar et al, 2012). Hal ini menunjukkan bahwa diperlukan pengembangan insektisida atau larvasida yang tidak berbahaya untuk lingkungan dan organisme hidup.

Salah satu tanaman yang memiliki potensi sebagai insektisida dan larvasida alami adalah tanaman duku (Lansium domesticum). Berdasarkan penelitian yang telah dilakukan, biji dan kulit buah duku mengandung alkaloid, flavonoid, saponin dan polifenol yang merupakan senyawa metabolit sekunder tanaman yang dapat memberikan efek terhadap aktivitas makan , pertumbuhan dan perkembangan, serta kematian atau mortalitas serangga (Isfaeni dkk, 2012).

\section{METODE}

Penelitian ini merupakan penelitian eksperimental yang dilakukan Laboratorium Entomologi, Departemen Parasitologi FKUI, Salemba, Jakarta. Rancangan penelitian yang digunakan adalah Rancangan Acak Lengkap (RAL).

Sampel yang digunakan adalah larva nyamuk Ae. aegypti instar III dan IV, karena stadium tersebut merupakan stadium aktif makan (WHO, 2005). Daun duku yang digunakan merupakan daun duku tua, yaitu helai ke-4 sampai ke-13, karena pada helai tersebut senyawa aktif pada daun telah sudah banyak dan stabil (Dwinatari \& Murti, 2015).

Ekstraksi dilakukan pada daun duku dengan dikeringkan selama \pm 1 minggu, lalu dihaluskan dengan blender. Kemudian daun duku direndam menggunakan metanol selama 24-48 jam. Hasil rendaman diaduk menggunakan maserator dan pelarut diuapkan menggunakan vacum evaporator (Houghton \& Raman, 1998).

Bioassay

dilakukan berdasarkan ketentuan WHO. Larva instar III dan IV Ae. aegypti sebanyak 25 ekor dimasukkan pada $200 \mathrm{ml}$ ekstrak pada tiap ulangan. Ekstrak daun duku menggunakan konsentrasi $0,2 \%, 0,4 \%, 0,6 \%, 0,8 \%$, dan $1,0 \%$. Setelah 24-48 jam diamati LC50 dan LC90 dari masing-masing konsentrasi ektrak daun duku (WHO, 2005).

Data hasil penelitian akan dianalisis dengan ANOVA dan Uji Probit menggunakan SPSS ver. 24. 
HASIL

Tabel 1. Persentase rerata kematian larva Ae. aegypti di berbagai konsentrasi ekstrak daun duku (Lansium domesticum)

\begin{tabular}{cccccccccccc}
\hline $\begin{array}{c}\text { Konsentrasi } \\
(\%)\end{array}$ & 1 & 2 & 3 & 4 & 5 & 6 & 7 & 8 & 24 & 48 \\
\cline { 2 - 11 } & 0 & 0 & 0 & 0 & 0 & 0 & 0 & 0 & 0 & 0 \\
0 & 0 & 0 & 0 & 0 & 0 & 0 & 2 & 6 & 70 & 100 \\
0,2 & 0 & 0 & 0 & 0 & 5 & 9 & 17 & 29 & 100 & 100 \\
0,4 & 0 & 0 & 0 & 0 & 2 & 4 & 50 & 67 & 100 & 100 \\
0,6 & 0 & 0 & 0 & 4 & 33 & 74 & 87 & 100 & 100 & 100 \\
0,8 & 0 & 11 & 16 & 52 & 89 & 100 & 100 & 100 & 100 & 100 \\
1,0 & & & & & & & & & & \\
\hline
\end{tabular}

Berdasarkan Tabel 1 terlihat bahwa pada konsentrasi ekstrak daun duku tertinggi yaitu $1,0 \%$ telah menimbulkan kematian larva Ae. aegypti sebesar $11 \%$, sedangkan pada konsentrasi ekstrak terendah yaitu $0,2 \%$ terlihat kematian larva dimulai setelah jam ke-7 sebesr $2 \%$.

Tabel 2. Pengaruh ekstrak daun duku terhadap larva Ae.aegypti selama 24 jam

\begin{tabular}{lcccccccccc}
\hline $\begin{array}{c}\text { Konsentrasi } \\
(\%)\end{array}$ & \multicolumn{4}{c}{$\begin{array}{c}\text { Jumlah kematian } \\
\text { larva 24 jam }\end{array}$} & Total & Rerata \pm SD & $\begin{array}{c}\text { Rerata } \\
(\%)\end{array}$ & $\begin{array}{c}\text { Nilai } \\
\mathbf{p}\end{array}$ \\
\cline { 2 - 5 } & $\mathbf{n}$ & $\mathbf{1}$ & $\mathbf{2}$ & $\mathbf{3}$ & $\mathbf{4}$ & & & 0 & 0,000 \\
\hline 0 & 25 & 0 & 0 & 0 & 0 & 0 & $0 \pm 0$ & 72 & \\
0,2 & 25 & 15 & 20 & 20 & 15 & 70 & $18 \pm 2,9$ & 100 & \\
0,4 & 25 & 25 & 25 & 25 & 25 & 100 & $25 \pm 0$ & 100 & \\
0,6 & 25 & 25 & 25 & 25 & 25 & 100 & $25 \pm 0$ & 100 & \\
0,8 & 25 & 25 & 25 & 25 & 25 & 100 & $25 \pm 0$ & 100 & \\
1,0 & 25 & 25 & 25 & 25 & 25 & 100 & $25 \pm 0$ & \\
\hline
\end{tabular}

Keterangan: 1,2,3, dan 4=ulangan, nilai $p=u j i$ Kruskal-Wallis

Tabel 2 menunjukkan bahwa setelah 24 jam pemaparan ekstrak daun duku (Lansium domesticum) terhadap larva Ae. aegypti hampir semua konsentrasi telah mematikan larva Ae. aegypti sebesar $100 \%$.

Tabel 3. Pengaruh ekstrak daun duku terhadap larva Ae.aegypti selama 48 jam

\begin{tabular}{|c|c|c|c|c|c|c|c|c|c|}
\hline \multirow{2}{*}{$\begin{array}{c}\text { Konsentrasi } \\
(\%)\end{array}$} & \multirow[b]{2}{*}{$\mathrm{N}$} & \multicolumn{4}{|c|}{$\begin{array}{c}\text { Jumlah kematian } \\
\text { larva } 48 \text { jam }\end{array}$} & \multirow[b]{2}{*}{ Total } & \multirow[b]{2}{*}{ Rerata \pm SD } & \multirow[b]{2}{*}{ Rerata (\%) } & \multirow[b]{2}{*}{ Nilai p } \\
\hline & & 1 & 2 & 3 & 4 & & & & \\
\hline 0 & 25 & 0 & 0 & 0 & 0 & 0 & $0 \pm 0$ & 0 & 0,000 \\
\hline 0,2 & 25 & 25 & 25 & 25 & 25 & 100 & $25 \pm 0$ & $100(25 / 25)$ & \\
\hline 0,4 & 25 & 25 & 25 & 25 & 25 & 100 & $25 \pm 0$ & $100(25 / 25)$ & \\
\hline 0,6 & 25 & 25 & 25 & 25 & 25 & 100 & $25 \pm 0$ & $100(25 / 25)$ & \\
\hline 0,8 & 25 & 25 & 25 & 25 & 25 & 100 & $25 \pm 0$ & $100(25 / 25)$ & \\
\hline 1,0 & 25 & 25 & 25 & 25 & 25 & 100 & $25 \pm 0$ & $100(25 / 25)$ & \\
\hline
\end{tabular}

Keterangan: $1,2,3$, dan $4=$ ulangan, nilai $p=u j i$ One Way ANOVA 
Berdasarkan Tabel 3, diketahui bahwa semua konsentrasi ekstrak daun duku dari $0,2 \%$ s.d. $1,0 \%$ telah menimbulkan kematian larva Ae. aegypti sebesar $100 \%$, dan pada kontrol tidak terjadi kematian.

Tabel 4. Nilai LC50 dan LC90

\begin{tabular}{lll}
\hline Waktu pemaparan & LC50 $(95 \% \mathrm{CI})$ & $\mathrm{LC} 90(95 \% \mathrm{CI})$ \\
\hline 2 jam & $1,62 \%(1,309-3,127)$ & $2,59 \%(1,801-9,024)$ \\
3 jam & $1,37 \%(1,167-2,167)$ & $2,06 \%(1,550-5,497)$ \\
4 jam & $1,06 \%(0,907-1,364)$ & $1,51 \%(1,226-3,153)$ \\
5 jam & $0,84 \%(0,728-0,922)$ & $1,01 \%(0,943-1,358)$ \\
6 jam & $0,72 \%(0,586-0,829)$ & $0,89 \%(0,780-1,377)$ \\
7 jam & $0,58 \%(0,506-0,633)$ & $0,82 \%(0,742-0,966)$ \\
24 jam & $0,51 \%(0,417-0,566)$ & $0,70 \%(0,616-0,889)$ \\
48 jam & $0,22 \%(0,178-0,252)$ & $0,32 \%(0,270-0,418)$ \\
\hline
\end{tabular}

Nilai LC50 dan LC90 merupakan konsentrasi ekstrak daun duku yang mampu membunuh 50\% dan $90 \%$ larva dari jumlah keseluruhan larva yang diuji. Berdasarkan tabel 4, terlihat bahwa nilai LC50 sebesar 0,22\% dan LC90 sebesar $0,32 \%$ selama 24 jam pemaparan ekstrak daun duku, sedangkan 48 jam ditemukan LC50 $0,07 \%$ dan LC90 0,12\%.
A

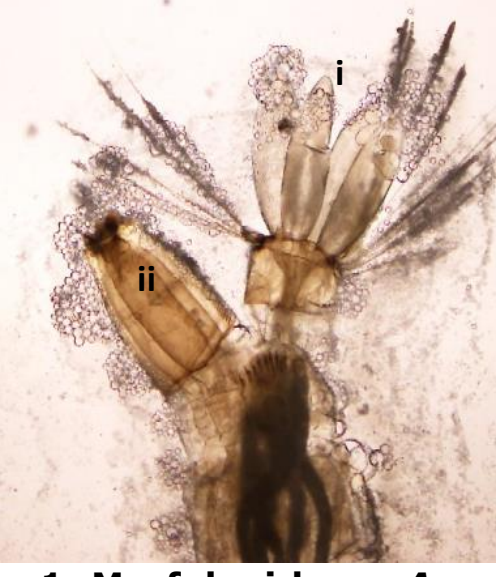

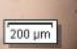

Gambar 1. Morfologi larva Ae. aegypti (A) kontrol, (B) pemaparan ekstrak daun duku, (i) papil anal, (ii) sifon

Gambar 1 menunjukkan perbedaan morfologi antara larva Ae. aegypti tanpa dan dengan pemaparan ekstrak daun duku (Lansium domesticum). Terlihat perbedaan utama terjadi pada papil anal larva.

\section{PEMBAHASAN}

Ekstraksi daun duku dalam penelitian ini menggunakan pelarut metanol yang memiliki indeks kepolaran sebesar 5,1 dan diyakini dapat melarutkan hampir semua senyawa metabolit sekunder dari tanaman (Firdaus dkk, 2015; Houghton \& Raman, 1998), seperti pada penelitian Suryanto dan Wehantouw (2008) menunjukkan bahwa penggunaan metanol dapat mengisolasi jumlah metabolit sekunder lebih banyak pada daun Artocarpus altilis $F$. dibandingkan dengan penggunaan etanol, karena itu penggunaan pelarut metanol dapat mempengaruhi aktivitas larvasida suatu ekstrak tanaman. 
Berdasarkan pada penelitian yang telah dilakukan, terlihat pada Tabel 1 bahwa pada konsentrasi ekstrak daun duku sebesar 0,2\% mulai mematikan larva Ae. aegypti setelah 7 jam pemaparan, hal ini kemungkinan dikarenakan kandungan pada ekstrak daun duku seperti alkaloid dan saponin yang merupakan senyawa yang berfungsi sebagai repellent (penolak) serangga, namun karena merupakan konsentrasi yang terendah sehingga ekstrak daun duku dengan konsentrasi 0,2\% membutuhkan waktu yang lebih lama untuk memberikan efek kematian pada larva (Gunawan, 2011).

Alkaloid dan saponin memiliki cara kerja sebagai larvasida dengan cara menghambat enzim asetilkolinesterase yang merupakan jembatan natrium dan pengantar impuls pada sistem saraf larva. Jika asetilkolinesterase terhambat, maka asetilkolin tidak dapat berdifusi ke membran pascasinaps untuk bergabung dengan suatu reseptor. Hal tersebut menyebabkan otot dan saraf, yang merupakan sistem yang terlebih dahulu mengalami kerusakan karena letaknya berada di bawah kutikula, tidak mengalami depolarisasi untuk permulaan kontraksi otot sehingga larva menjadi kejang dan dapat menimbulkan kematian (De Geyter et al, 2007).

Berdasarkan tabel 1,2, dan 3, konsentrasi ekstrak daun duku 0,4\% dan $0,6 \%$ menimbulkan kematian larva $100 \%$ setelah pemaparan 24 jam, hal tersebut dikarenakan alkaloid yang terkandung juga dapat berperan sebagai racun perut yang dapat masuk kedalam tubuh larva dan mengganggu sistem pencernaan sehingga dapat menimbulkan kematian pada larva (Mardiana, 2009; Ni'mah, 2014). Makanan larva berupa pelet yang dimasukkan ke dalam ekstrak akan masuk ke dalam metabolisme sel larva lalu menghambat proses metabolisme sel berupa transport elektron dalam mitokondria, sehingga tidak terjadi pembentukan energi dari makanan dan sel mengalami hambatan dalam aktivitasnya. Sejalan dengan penelitian Fidiana dkk (2013) bahwa alkaloid dapat meracuni larva melalui caranya mengambil makanan yang ada di permukaan air. Selain itu, alkaloid juga dapat menghambat 3 hormon pertumbuhan larva, yaitu hormon otak, hormon ekdison, dan hormon pertumbuhan. Tidak berfungsi dengan baiknya ketiga hormon tersebut dapat menyebabkan larva gagal bermetamorfosis menjadi pupa dan akhirnya larva akan mati (Fidiana, 2013).

Flavonoid merupakan senyawa pertahanan tumbuhan yang dapat bersifat menghambat nafsu makan serangga. Saponin dapat menghambat kerja proteolitik yang menyebabkan penurunan aktivitas enzim pencernaan dan penggunaan protein. Tannin dapat menurunkan kemampuan mencerna makanan pada serangga dengan cara menurunkan aktivitas enzim pencernaan. Eugenol bertindak sebagai racun perut dan menghambat reseptor perasa pada mulut larva (Gunawan, 2011). Karena itu pada konsentrasi ekstrak daun duku $1,0 \%$ sudah dapat mematikan larva sebesar $100 \%$ pada jam ke-2. Hal tersebut dapat terjadi karena pada konsentrasi $1,0 \%$ senyawa aktif pada ekstrak daun duku lebih banyak dibandingkan konsentrasi lain.

Saponin diketahui memiliki efek anti serangga, karena dapat menurunkan aktivitas enzim pencernaan dan penyerapan makanan. Saponin juga dapat mengikat sterol bebas dalam pencernaan serangga karena sterol berperan sebagai prekursor hormon ekdison. Jumlah sterol bebas yang turun dapat mengganggu proses pergantian kulit pada serangga (molting) dan senyawa ini juga berinteraksi dengan membran kutikula larva sehingga dapat merusak lapisan membran dari larva. Saponin merupakan senyawa yang memiliki aktivitas anti makan (antifeedant) dan dapat menghambat pertumbuhan dan dapat berinteraksi 
dengan membran kutikula sehingga menimbulkan kerusakan dan menyebabkan kematian pada larva (Chaieb, 2010; De Geyter et al, 2007; Deore \& Khadabadi, 2009; Elumalai et al, 2013; Gunawan, 2011).

Pada tabel 4 menunjukkan nilai LC50 dan LC90 ekstrak yang dapat menimbulkan kematian pada larva perlakuan sebesar $50 \%$ dan $90 \%$. Kematian larva Ae. aegypti pada konsentrasi ekstrak daun duku 0,2\%$1,0 \%$ dianalisis menggunakan analisis probit dan didapatkan LC50 dan LC90 dalam waku 24 jam sebesar $0,2 \%$ dan 0,3\%, dan dalam waktu 48 jam LC50 sebesar $0,7 \%$ dan LC90 sebesar $0,12 \%$. Hal ini menunjukkan bahwa konsentrasi ekstrak daun duku yang dibutuhkan semakin kecil seiring dengan lamanya waktu pemaparan.

Penelitian yang dilakukan Ni'mah dkk (2014) pada ekstrak etanol biji duku terhadap kematian larva $A e$. aegypti menunjukkan nilai LC50 sebesar $9367,5 \mathrm{ppm}$ atau setara dengan $0,9 \%$, sedangkan penelitian Monzon et al (1994) menggunakan ekstrak air daun segar tanaman duku terhadap kematian larva Ae. aegypti memiliki nilai LC50 16,3316\% setelah 48 jam pemaparan. Nilai LC50 ekstrak daun duku pada penelitian ini berbeda dengan penelitian-penelitian sebelumnya karena memiliki nilai LC50 lebih rendah yaitu 0,2\% dengan waktu pemaparan lebih singkat yaitu 24 jam. Hal tersebut dikarenakan penggunaan bagian tanaman yaitu daun dan penggunaan pelarut metanol. Berdasarkan penelitian Suryanto dan Wehantouw (2008) pelarut metanol dapat menarik hasil metabolit sekunder pada tanaman lebih maksimal sehingga senyawa aktif yang memiliki efek larvasida semakin banyak didapat dalam suatu ekstrak.

Pada larva perlakuan juga terlihat perubahan pada sifon, yaitu menjadi lebih menghitam jika dibandingkan dengan larva kontrol, hal tersebut menjadi berbahaya terhadap kehidupan larva dikarenakan larva yang hidup dalam air dapat mengalami kerusakan pada permukaan hidrofobik sehingga air dapat masuk dan membahayakan sistem pernapasan dari larva karena pada ujung sifon terdapat spirakel yang merupakan alat pernapasan bagi larva. Gangguan sistem osmoregulator dari kerusakan papil anal dan sistem respirator dari rusaknya sifon dapat berkontribusi pada kematian larva (Yu et al, 2015).

\section{KESIMPULAN}

Berdasarkan penelitian yang telah dilakukan dapat disimpulkan bahwa ekstrak daun duku (Lansium domesticum) memiliki pengaruh terhadap kematian larva Ae. aegypti. Konsentrasi ekstrak daun duku yang paling efektif yaitu $0,2 \%$ dengan nilai LC50 dan LC90 setelah 24jam masing-masing adalah $0,22 \%$ dan $0,32 \%$.

\section{DAFTAR PUSTAKA}

Chaieb, I. (2010). Saponins as Insecticides: a Review. Tunisian Journal of Plant Protection, 5(1), 39-50.

De Geyter, E., Lambert, E., Geelen, D., \& Smagghe, G. (2007). Novel advances with plant saponins as natural insecticides to control pest insects. Pest Technology, 1(2), 96-105.

Deore, S. L., \& Khadabadi, S. S. (2009). Larvicidal activity of the saponin fractions of Chlorophytum borivilianum santapau and Fernandes. Journal of Entomology and Nematology, 1(November), 64-66.

Dwinatari, I. K., \& Murti, Y. B. (2015). Pengaruh waktu pemanenan dan tingkat maturasi daun terhadap kadar viteksikarpin dalam daun legundi (Vitex trifolia L.). Traditional Medicine Journal, 20(2), 105-111.

Elumalai, K., Dhanasekaran, S., \& Krishnappa, K. (2013). Larvicidal activity of Saponin isolated from Gymnema sylvestre $\mathrm{R}$. $\mathrm{Br}$. (Asclepiadaceae) against 
Japanese Encephalitis vector, Culex tritaeniorhynchus Giles (Diptera: Culicidae). European Review for Medical and Pharmacological Sciences, 17(10), 1404-1410.

Fidiana, D. F., Mifbakhudin, \& Nurullita, U. (2013). Daya Bunuh Ekstrak Kulit Duku ( Lansium Domesticum Corr ) Terhadap Kematian Larva Aedes aegypti. Jurnal Kesehatan Masyarakat, 8(2), 2013.

Firdaus, I., Retnowati, R., \& Sutrisno. (2015). Fraksinasi Ekstrak metanol Daun Mangga Kasturi ((Mangifera casturi Kosterm) Dengan Pelarut n-Butanol. Kimia Student Journal, 1(1), 787.

Guerdan, B. (2010). Dengue fever/dengue hemorrhagic fever. Am. J. Clin. Med., 7(2), 51-53.

Gunawan, E. (2011). Efek potensial larvasida kombinasi ekstrak daun kemangi (Ocimum sanctum Linn) dan biji jarak (Ricinus communis Linn) terhadap Aedes aegypti. Universitas Sebelas Maret.

Houghton, P. J., \& Raman, A. (1998). Laboratory Handbook for the Fractionation of Natural Extracts.

Isfaeni, H., Filani, R., \& Pertiwi, A. (2012). Repellency of Lansium domesticum peels extract to Nilaparvata lugens ( Homoptera ) on Oryza sativa IR 42, 1(10), 13220.

Kemenkes. (2015). Demam berdarah biasanya mulai meningkat di januari. Demam Berdarah Biasanya Mulai Meningkat Di Januari, 5-6.

Kumar, S., Wahab, N., Mishra, M., \& Warikoo, R. (2012). Evaluation of 15 local plant species as larvicidal agents against an Indian strain of dengue fever mosquito, Aedes aegypti L. (Diptera: Culicidae). Frontiers in Physiology, 3 $A P R($ April), 1-6.

Mardiana, Supraptini, \& Aminah, N. S. (2009). Datura me tel linnaeus Sebagai Insektisida dan Larvasida Botani serta Bahan Baku Obat Tradisional. Media
Penelitian Dan Pengembangan Kesehatan, 19.

Ni'mah, T., Oktarina, R., Mahdalena, V., \& Asyati, D. (2014). Potensi ekstrak biji duku (Lansium domesticum Corr) terhadap Aedes aegypti. Buletin Penelitian Kesehatan, 43(2), 131-136.

Safar, R. (2009). Parasitologi kedokteran: protozoologi, helmintologi, entomologi. Bandung: CV. Yrama Widya.

WHO. (2005). Guidelines for laboratory and field testing of mosquito larvicides. World Health Organization, 1-41.

Wong, P. S. J., Li, M. zhi I., Chong, C. S., Ng, L. C., \& Tan, C. H. (2013). Aedes (Stegomyia) albopictus (Skuse):a potential vector of zika virus in Singapore. PLoS Neglected Tropical Diseases, 7(8), 1-5.

Yu, K. X., Wong, C. L., Ahmad, R., \& Jantan, I. (2015). Larvicidal activity, inhibition effect on development, histopathological alteration and morphological aberration induced by seaweed extracts in Aedes aegypti (Diptera: Culicidae). Asian Pacific Journal of Tropical Medicine, 8(12), 1006-1012. 